\title{
PENINGKATAN KEPUASAN KONSUMEN MELALUI PENGGUNAAN E-COMMERCE
}

\author{
Dwi Rorin Mauludin Insana ${ }^{1}$, Ria Susanti Johan ${ }^{2}$ \\ ${ }^{1,2}$ Universitas Indraprasta PGRI Jakarta \\ Email: dwirorin@gmail.com
}

Diterima: 8 Juni 2020; Direvisi: 27 Juli 2020; dipublikasikan: 28 Agustus 2020

\begin{abstract}
ABSTRAK
Berbelanja melalui e-commerce telah memudahkan para pembeli yang sibuk dan tidak memiliki waktu untuk pergi berbelanja barang yang dicari atau dibutuhkan dan pastinya menghemat waktu dan tenaga serta lebih mudah, praktis, mudah dicari, informasi yang diberikan lebih detail serta biasanya harga yang ditawarkan lebih terjangkau bahkan lebih murah dibandingkan dari harga di pasar. Penelitian ini bertujuan untuk mengetahui lebih mendalam tentang pengaruh $e$-commerce terhadap kepuasan konsumen pada usaha kecil menengah. Penelitian ini dilakukan dengan pemberian angket kepada 45 responden. Data diolah dan dianalisis menggunakan regresi linier sederhana untuk mengetaui hubungan antara variabel X dan Y dengan bantuan software SPSS Versi 20. Berdasarkan hasil dan pembahasan dapat disimpulkan bahwa terdapat hubungan yang positif dan pengaruh yang signifikan antara variabel $e$ commerce dengan kepuasan konsumen. Hal ini dibuktikan dengan angka korelasi antara e-commerce dengan kepuasan pelanggan adalah sebesar 0,568 yang berarti memiliki hubungan yang positif, sedangkan dari hasil pengujian hipotesis diperoleh $t_{\text {hitung }}$ sebesar 5,50 dan $t_{\text {tabel }}$ sebesar 1,681, ini berarti bahwa $t_{\text {hitung }}>t_{\text {tabel}}$, maka Ha diterima dan Ho ditolak. Sehingga dapat diambil kesimpulan bahwa terdapat pengaruh yang signifikan antara e-commerce dengan kepuasan konsumen. Hal ini berarti bahwa penggunaan $e$-commerce yang baik dan professional dapat meningkatkan kepuasan konsumen.
\end{abstract}

Kata Kunci : e-commerce, teknologi informasi, kepuasan, konsumen, usaha kecil menengah

\begin{abstract}
Shopping through e-commerce has made it easier for buyers who are busy and do not have the time to go shopping for items that are sought or needed and certainly save time and effort and are easier, more practical, easy to find, the information provided is more detailed and usually the prices offered are more affordable even cheaper than the prices on the market. This study aims to find out more about the influence of e-commerce on consumer satisfaction in small and medium businesses. This research was conducted by giving questionnaires to 45 respondents. Data were processed and analyzed using simple linear regression to find out the relationship between variables X and Y with the help of SPSS Version 20. Based on the results and discussion, it can be concluded that there is a positive relationship and significant influence between e-commerce variables and customer satisfaction. This is evidenced by the correlation rate between e-commerce and customer satisfaction is 0.568 which means it has a positive relationship, while the results of testing the hypothesis obtained by $t_{\text {count }}$ of 5.50 and $t_{\text {table }}$ of 1.681 , this

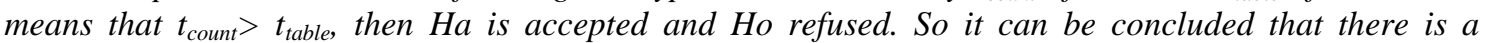
significant influence between e-commerce and customer satisfaction. This means that the use of good and professional e-commerce can increase customer satisfaction.
\end{abstract}

Keywords: e-commerce, information technology, satisfaction, customer, small and medium enterprises 


\section{sosio e-kons}

Volume 12, No. 2, Agustus 2020, pp. 125-137

e-ISSN: $2502-5449$

p-ISSN: 2085-2266

DOI : $10.30998 /$ sosioekons.v12i02.6451

\section{PENDAHULUAN}

Seiring dengan berkembangnya zaman, dunia teknologi dan informasi pun ikut berkembang secara pesat. Di berbagai belahan dunia hampir semua orang bersentuhan secara langsung dengan dunia internet. Semua informasi, berita, dan apa pun yang sedang terjadi di berbagai tempat dapat dengan mudah di akses dari internet dari berbagai narasumber. Indonesia menjadi salah satu negara yang sangat besar terkena dampaknya dalam perkembangan teknologi dan informasi. Hampir semua rakyat Indonesia bisa dengan mudah menyerap informasi yang diterima yang bersumber dari dunia digital ini, baik diserap secara mentah maupun dicari tahu kembali kebenarannya.

Menurut lembaga riset pasar e-Marketer yang melakukan riset pada 2014 menghasilkan bahwa populasi netter di Indonesia pada 2014 mencapai 83,7 juta orang dan menempati peringkat ke enam. E-Marketer memperkirakan netter Indonesia akan mencapai 112 juta orang pada 2017 dan bisa saja mengalahkan Jepang di peringkat kelima yang pertumbuhan internetnya lebih lamban.

Survei lain yang dilakukan oleh Asosiasi Penyelenggara Jaringan Internet Indonesia (APJII) menemukan fakta baru bahwa ternyata sepanjang 2016 sebanyak 132,7 juta orang di Indonesia telah terhubung ke internet. Adapun total penduduk Indonesia sebanyak 256,2 juta orang. Penyebabnya adalah karena perkembangan infrastruktur dan mudahnya mendapatkan smartphone pada saat ini (Norhermaya, 2016).

Jika di era dahulu para penjual harus menjual barang atau jasa yang mereka tawarkan dengan berjualan di toko atau lapak, sekarang penjual dapat secara online melakukannya. Setiap orang bisa dengan mudah mengakses dan melakukan transaksi tanpa harus bertatap muka dengan penjual atau pembeli. Pilihan tempat yang ditawarkan pun telah bervariasi. Kegiatan online shopping ini merupakan suatu bentuk komunikasi baru yang tidak memerlukan komunikasi dengan tatap muka secara langsung, melainkan dapat dilakukan dengan cara terpisah, dari dan ke seluruh dunia melalui media komputer, laptop dan handphone yang telah terhubung langsung dengan layanan akses internet.

Perkembangan e-commerce di Indonesia sendiri telah berlangsung seiring berkembangnya internet sejak pertama kali masuk ke Indonesia sekitar 1990-an. Saat ini kegiatan e-commerce di Indonesia telah merambah ke berbagai jenis kegiatan bisnis. Dari skala industri kecil sampai industri yang besar (Norhermaya, 2016).

Berbelanja melalui e-commerce juga memudahkan para pembeli yang sibuk dan tidak memiliki waktu untuk pergi berbelanja barang yang dicari atau dibutuhkan dan pastinya menghemat waktu dan tenaga. Dengan maraknya kegiatan e-commerce saat ini, juga telah memberikan manfaat yang cukup besar, yaitu lebih mudah, praktis, mudah dicari, informasi yang diberikan lebih detail serta biasanya harga yang ditawarkan lebih terjangkau bahkan lebih murah dibandingkan dari harga di pasar.

Menjamurnya marketplace yang menjadi salah satu wadah dari e-commerce di Indonesia, baik hasil karya anak bangsa sendiri maupun milik asing memudahkan penjual untuk memilih lokasi atau marketplace mana saja yang akan dijadikan lokasi untuk menjual produknya. Banyaknya marketplace seperti Tokopedia, Bukalapak, MatahariMall, Lazada, Elevenia dan lainnya menjadi pilihan tersendiri bagi pihak penjual.

Pemanfaatan e-commerce saat ini sudah hampir merata di kalangan masyarakat umum termasuk kalangan usaha kecil menengah. Hasil dari penelitian (Maya, 2016) menyatakan bahwa strategi penjualan melalui e-commerce mengalami peningkatan sebesar 348\% dari 2014 ke 2015. Peningkatan juga terjadi 2015 sampai Juli 2016 sebesar 25\%. Hal yang dilakukan pengusaha melalui e-commerce yaitu pendekatan kepada pelanggan dan memberikan kemudahan dalam melakukan transaksi pembelian. Sektor usaha yang diminati pasar adalah sektor makanan (food), fashion, dan rumah tangga. Kesimpulan dari penelitian ini adalah 


\section{sosio e-kons}

Volume 12, No. 2, Agustus 2020, pp. 125-137

e-ISSN: $2502-5449$

p-ISSN: 2085-2266

DOI : $10.30998 /$ sosioekons.v12i02.6451

peningkatan penjualan efektif dan efisien dapat dilakukan melalui $e$-commerce.

Berdasarkan hasil penelitian (Astuti \& Salisah, 2016) menyatakan bahwa harapan pelanggan terhadap layanan e-commerce di Lejel Home Shopping lebih besar dari pelayanan yang diperoleh, sehingga pelayanan yang diberikan masih belum memuaskan pelanggan. Walaupun berjualan melalui e-commerce jarang adanya tatap muka dengan konsumen tetapi kepuasan konsumen tetaplah menjadi hal yang diutamakan. Beberapa layanan e-commerce yang diutamakan untuk kepuassan konsumen adalah layanan transaksi di e-commerce dilakukan selama 24 jam, pengiriman barang sesuai dengan yang dipesan oleh pelanggan, halaman pada $e$ commerce tidak mengalami hang saat melakukan transaksi, semua informasi yang ada di $e$ commerce adalah benar, tidak terjadi perubahan harga produk ketika telah terjadi transaksi pembelian barang, pihak Lejel Home Shopping selalu cepat dan tepat dalam memenuhi keinginan pelanggan, stok barang ditulis di e-commerce selalu ready, terdapat alamat kantor cabang daerah yang bisa dikunjungi oleh pelanggan, pihak Lejel Home Shopping menyelesaikan keluhan atau masalah dari pelanggan dengan cepat, Link-link yang disediakan mudah di klik (mudah menyambung ke tujuan link), pengelola e-commerce Lejel Home Shopping menyediakan layanan secara dengan online (Facebook, Twitter, Blog, Chat dan lain sebagainya), penawaran yang diberikan sesuai apa adanya, pihak Lejel Home Shopping cepat dalam memberikan informasi kepada pelanggan.

Kemudian dari hasil penelitian (Lestari, 2018) menunjukkan adanya pengaruh web $e$ commerce ,kualitas produk dan layanan terhadap kepuasan konsumen. Hal ini menjadikan tantangan tersendiri karena mengandalkan komunikasi dengan bahasa yang baik dan tepat kepada konsumen, sehingga konsumen merasa terpuaskan akan kebutuhannya saat berbelanja. Berbeda halnya apabila bertatap muka dengan konsumen secara langsung dimana penjual bisa dengan tahu apakah konsumen merasa puas atau tidak terhadap pelayanan dan kebutuhannya saat berbelanja.

Berdasarkan uraian di atas, dirasa perlu untuk mengetahui pengaruh $e$-commerce terhadap kepuasan konsumen terutama pada usaha kecil menengah.

\section{E-commerce}

Menurut (Komputer, 2002) bahwa e-commerce merupakan salah satu keunggulan dari internet, hingga akhirnya di era sekarang ini (yang disebut dengan era digital) e-commerce memiliki banyak sebutan yaitu internet commerce, e-com, e-commerce atau immerce yang berarti membeli atau menjual secara elektronik, dan kegiatan ini dilakukan pada jaringan internet. Kegiatan e-bussiness dengan e-commerce merupakan satu kesatuan yang tidak bisa dipisahkan (Chandra, Ahmad dan Dadang, 2013). Hidayat, (2008) berpendapat bahwa $e$ commerce sudah menjadi bagian dari e-lifestyle yang memungkinkan suatu transaksi jual beli dilakukan secara online dari lokasi dimanapun. Selain itu dengan adanya pemanfaatan teknologi informasi seperti e-commerce ini dapat meningkatkan motivasi orang untuk berwirausaha dan meningkatkan pendapatan (Insana \& Hapsari, 2019). Begitu juga dengan para pengusaha bisa memanfaatkan teknologi informasi untuk pengembangan bisnisnya terutama sebaga media promosi dan penjualan (Irmawati, 2011), (Insana et al., 2019).

Menurut Wong, (2010) bahwa pengertian dari e-commerce adalah pembelian, penjualan dan pemasaran barang serta jasa melalui sistem elektronik, seperti radio, televisi dan jaringan komputer atau internet, sedangkan Varmaat, (2007) mendefinisikan bahwa e-commerce merupakan transaksi bisnis yang terjadi dalam jaringan elektronik, seperti internet. Siapapun yang mempunyai jaringan internet dapat berpartisipasi dalam kegiatan e-commerce.

Laudon (2007) membagi transaksi e-commerce ke dalam tiga jenis berdasarkan sifat peserta yang terlibat dalam transaksi e-commerce. Ketiga jenis tersebut, yaitu (a).Business to consumers (B2C), yaitu bisnis tersebut melibatkan penjualan produk dan layanan secara eceran kepada pembeli perorangan, (b). Business to business (B2B), yaitu bisnis tersebut melibatkan 


\section{sosio e-kons}

Volume 12, No. 2, Agustus 2020, pp. 125-137

e-ISSN: $2502-5449$

p-ISSN: 2085-2266

DOI : 10.30998/sosioekons.v12i02.6451

penjualan produk dan layanan antarperusahaan, (c). Consumer to consumers (C2C), yaitu bisnis yang melibatkan konsumen yang menjual secara langsung ke konsumen.

Menurut Hidayat (2008) bahwa e-commerce sendiri memiliki beberapa komponen standar yang dimiliki dan tidak dimiliki transaksi bisnis yang dilakukan secara offline, yaitu:

a) Produk

Banyak jenis produk yang bisa dijual melalui internet, seperti komputer, buku, musik, pakaian, mainan, dan lain-lain.

b) Tempat menjual produk ( a place to sell)

Tempat menjual adalah internet yang berarti harus memiliki domain dan hosting.

c) Cara menerima pesanan

E-mail, telepon, sms dan lain-lain.

d) Cara pembayaran

Cash, cek, bank draft, kartu kredit, internet payment (misalnya paypal).

e) Metode pengiriman

Pengiriman bisa dilakukan melalui paket, salesman, atau di download jika produk yang dijual memungkinkan untuk itu (misalnya software).

f) Customer service

E-mail, formulir online, FAQ, telepon, chatting, dan lain-lain.

Berdasarkan penjelasan para ahli di atas, penulis menyimpulkan bahwa e-commerce adalah suatu kegiatan bisnis dimana bisnis yang dilakukan berada pada penggunaan teknologi elektronik seperti handphone, laptop, PC, serta memiliki jaringan internet. E-commerce sendiri memudahkan seorang penjual kepada calon pembeli ataupun pembelinya dalam melakukan transaksi. Hal ini dapat dilihat bahwa tidak perlunya penjual dan pembeli untuk bertatap muka serta kemudahan dalam melakukan pembayaran yang bisa dilakukan melalui transfer antar rekening ataupun melalui rekening bersama untuk beberapa marketplace.

\section{Kepuasan Konsumen}

Menurut Aritonang, (2005) bahwa kepuasan konsumen atau pelanggan sebagai hasil penilaian pelanggan terhadap yang diharapkannya dengan membeli dan mengonsumsi suatu produk. Harapan itu lantas dibandingkan dengan persepsinya terhadap kinerja yang diterimanya dengan mengonsumsi produk itu. Jika harapannya lebih tinggi daripada kinerja produk maka ia akan merasa tidak puas. Sebaliknya jika harapannya sama dengan atau lebih rendah daripada kinerja produk ia akan merasa puas.

Kepuasan Konsumen merupakan ukuran kinerja 'produk total' sebuah organisasi dibandingkan serangkaian keperluan pelanggan. Kepuasan pelanggan bukanlah konsep absolut, melainkan relatif atau tergantung pada apa yang diharapkan pelanggan (Tjiptono, Fandy dan Chandra, 2016), sedangkan menurut Kotler, (2005) bahwa kepuasan pelanggan adalah perasaan senang atau kecewa seseorang yang timbul karena membandingkan kinerja yang dipersepsikan produk (hasil) terhadap ekspetasi mereka. Jika kinerja gagal memenuhi ekspetasi, pelanggan akan tidak puas. Jika kinerja sesuai dengan ekspetasi, pelanggan akan puas. Jika kinerja melebihi ekspetasi, pelanggan akan sangat puas dan senang.

Berdasarkan uraian di atas ada dua hal penting yang menjadi tolok ukur akan kepuasan konsumen. Pertama, adalah manfaat akan kegunaan barang tersebut. Seorang konsumen membeli barang yang bermanfaat sesuai dengan kebutuhannya ataupun keinginannya. Saat konsumen tersebut mendapatkan barang yang mereka inginkan dan dapat digunakan akan manfaat barang tersebut, konsumen akan merasa puas dari segi pemanfaatan produk. 
Kedua adalah pelayanan yang diberikan oleh penjual pada saat konsumen melakukan transaksi. Pelayanan yang baik yang diberikan oleh penjual kepada konsumen tersebut juga menjadi nilai tambah tersendiri karena konsumen merasa terpenuhi akan setiap pertanyaan dan kebutuhannya.

Memuaskan kebutuhan konsumen adalah keinginan dari setiap perusahaan. Hal ini karena sebagai salah saktu faktor utama agar perusahaan dapat berjalan dengan sebaiknya. Dengan perusahaan mampu memuaskan konsumen, akan membuat perusahaan menjadi yang paling unggul dalam persaingan karena berhasil mendapatkan kepercayaan konsumen.

Para konsumen yang merasa puas terhadap produk dan jasa pelayanan yang diberikan akan lebih cenderung untuk kembali membeli produk barang tersebut, ataupun kembali menggunakan jasa tersebut pada saat kebutuhan akan produk tersebut muncul lagi dikemudian hari.

Dapat disimpulkan bahwa, kepuasan merupakan salah satu faktor kunci bagi konsumen dalam melakukan pembelian secara continue. Selain itu, pelanggan yang merasa puas akan merekomendasikan produk atau jasa yang digunakannya kepada orang lain, sehingga merupakan salah satu faktor meningkatnya volume penjualan perusahaan tersebut.

Kepuasan konsumen timbul dari adanya respon emosional terhadap produk yang digunakan, khususnya ketika mereka membandingkan kinerja yang konsumen rasakan dibanding dengan harapannya yang prosesnya seperti pada gambar 1 (Hasan, 2008).

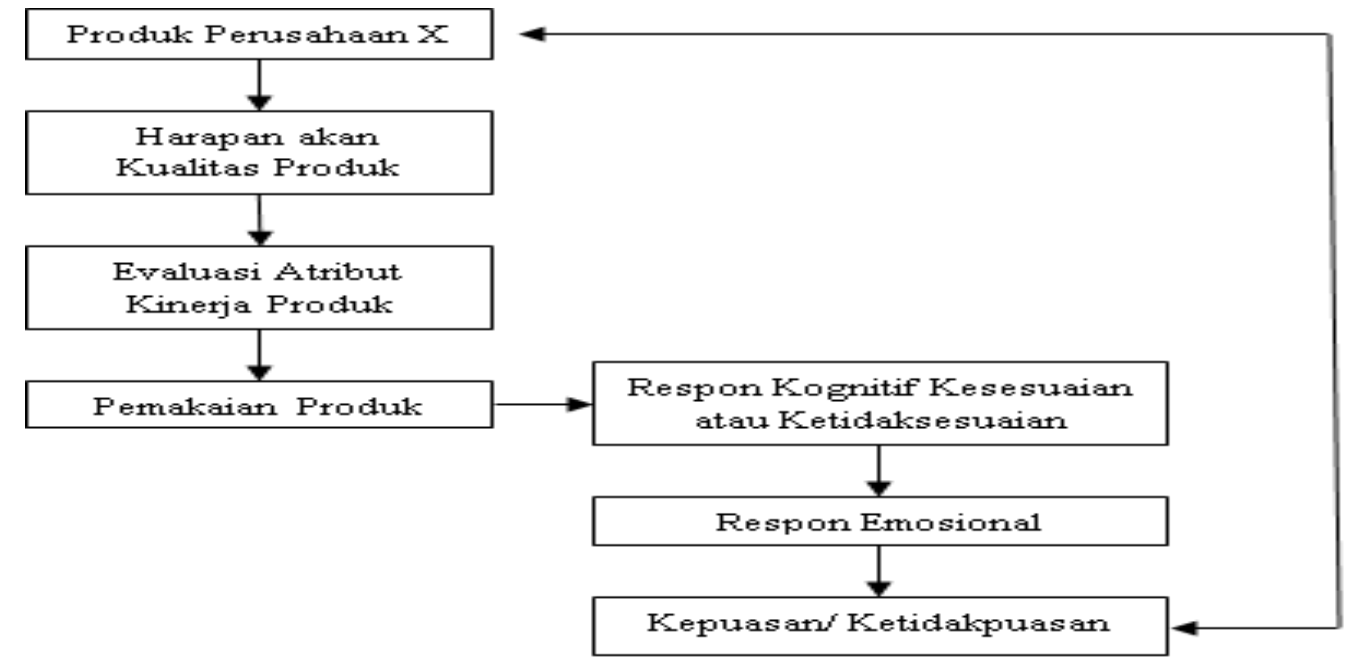

Sumber: Hasan (2008: 58)

Gambar 1. Model Kepuasan-Ketidakpuasan Konsumen

Menurut Irawan, (2008) ada lima faktor yang perlu diperhatikan oleh penjual dalam menentukan kepuasan konsumen, antara lain:

a. Kualitas produk, yaitu pelanggan akan merasa puas bila hasil mereka menunjukkan bahwa produk yang mereka gunakan berkualitas.

b. Kualitas pelayanan dan jasa, yaitu pelanggan akan merasa puas apabila mereka mendapatkan pelayanan yang baik atau sesuai dengan yang diharapkan.

c. Emosi, yaitu pelanggan akan merasa bangga dan mendapatkan keyakinan bahwa orang lain akan merasa bangga dan mendapatkan keyakinan bahwa orang lain akan kagum terhadap dia apabila menggunakan produk dengan merk tertentu yang cenderung mempunyai tingkat kepuasan yang lebih tinggi. Kepuasan yang didapat bukan karena kualitas dari produk tetapi karena sosial atau self esteem yang membuat pelanggan merasa puas terhadap merk tertentu. 


\section{sosio e-kons}

Volume 12, No. 2, Agustus 2020, pp. 125-137

e-ISSN: $2502-5449$

p-ISSN: 2085-2266

DOI : $10.30998 /$ sosioekons.v12i02.6451

d. Harga, yaitu produk yang mempunyai kualitas yang sama, tetapi menetapkan harga yang lebih murah akan memberikan nilai lebih tinggi kepada pelanggan.

e. Biaya, yaitu pelanggan tidak perlu mengeluarkan biaya tambahan atau tidak perlu membuang waktu untuk mendapatkan suatu produk atau jasa cenderung puas terhadap produk atau jasa tersebut.

Harapan pelanggan saat membeli sebenarnya mempertimbangkan fungsi produk tersebut. Bila fungsi produk sesuai dengan apa yang diharapkan, konsumen akan merasa terpuaskan, sehingga dapat disimpulkan kepuasan konsumen adalah suatu sikap dan kondisi seorang konsumen merasa bahwa semua kebutuhan akan produk barang ataupun jasa yang dia butuhkan, baik itu informasi, kegunaan, maupun manfaat dari barang dan jasa tersebut sudah terpenuhi.

Selain itu, pelayanan yang diberikan oleh seorang penjual juga menjadi nilai tambah yang bisa membuat konsumen merasa puas. Efek dari kepuasan konsumen ini membuat konsumen akan menjadi loyal terhadap penjual tersebut dan akan melakukan pembelian secara terus menerus serta tidak ragu untuk merekomendasikan barang atau jasa yang digunakannya kepada orang-orang terdekatnya.

\section{Hubungan E-commerce dengan Kepuasan Konsumen}

Perdagangan elektronik atau e-commerce juga memiliki kaitan yang erat dengan kepuasan konsumen. Hal ini karena dengan adanya e-commerce memberikan manfaat bagi konsumen, seperti konsumen bebas melakukan transaksi selama 24 jam di lokasi manapun, memberikan pilihan bagi konsumen untuk memilih ingin berbelanja di vendor yang diinginkan, sehingga dapat membandingkan harga untuk produk yang sejenis (Nisar \& Prabhakar, 2017), (Kassim \& Asiah Abdullah, 2010), Fasanghari, (2008) E-commerce merupakan suatu proses dalam berbisnis dimana bisnis tersebut menggunakan media elektronik dan teknologi sebagai dasar utama. Hal ini karena dalam e-commerce mengutamakan penjualan tanpa harus membuat seorang penjual membuka toko atau lapaknya dalam bentuk fisik. Semua kalangan baik mereka pengusaha kecil maupun pengusaha besar dapat dengan mudah berjualan dalan e-commerce ini.

Perilaku seorang konsumen di internet jauh lebih rumit dibandingkan perilaku konsumen offline, karena adanya pengaruh teknologi Web. Diana, (2007) berpendapat bahwa kepuasan konsumen internet dipengaruhi beraneka ragam faktor antara lain (a) Dukungan logistik, (b) Layanan pelanggan, (c) Daya tarik penetapan harga, (d) Website store front, yang ditentukan oleh beberapa elemen, seperti keamanan (privasi dan keamanan transaksi), reliabilitas sistem, kecepatan operasi, kemudahan penggunaan, konten dan kualitas (di antaranya format, reliabilitas, kelengkapan, dan ketepatan waktu). Dalam konteks e-commerce, kepuasaan pelanggan biasanya didefinisikan sebagai pelanggan membandingkan dari suatu perusahan $e$ commerce lainnya yang menyebabkan pelanggan re-purchase. Kepuasaan pelanggan dapat didefinisikan sebagai sikap pelanggan yang menguntungkan terhadapat e-commerce, mengakibtakan melakukan pembelian ulang (Widyanita, 2018).

Segala macam transaksi yang dilakukan melalui media internet mengandalkan bagaimana reaksi konsumen terhadap barang atau jasa yang dipesan, apakah sesuai dengan fungsi atau ekspetasi konsumen atau tidak, sehingga konsumen dapat merasa puas atau tidak puas. Selain itu, faktor lain, eperti kualitas pelayanan, informasi yang jelas, design website yang simple dan memudahkan konsumen, harga yang sesuai serta keamanan dalam bertransaksi juga menjadi hal yang penting. Hal ini akan membuat konsumen merasa terpuaskan, tidak hanya dari segi manfaat produk saja, tetapi faktor yang disebutkan sebelumnya, sehingga apabila konsumen merasa terpuaskan, konsumen tersebut akan melakukan pembelian secara continue dan akan ada kemungkinan konsumen tersebut akan memberitahukan kepada sekitar untuk melakukan pembelian di toko tersebut.

Penjualan melalui e-commerce juga memerlukan perhatian khusus. Hal ini tidak bertatap mukanya antara penjual dan pembeli menyebabkan penjual tidak mengetahui pelayanan yang 


\section{sosio e-kons}

Volume 12, No. 2, Agustus 2020, pp. 125-137

e-ISSN: $2502-5449$

p-ISSN: 2085-2266

DOI : 10.30998/sosioekons.v12i02.6451

telah diberikan, informasi produk yang diberikan dan apakah sudah memuaskan dari pihak konsumen ataukah belum. Faktor lainnya, seperti keamanan dalam bertransaksi juga menjadi hal yang penting, sehingga akan berujung pada kepuasan konsumen, sehingga apabila faktorfaktor penyebab kepuasan konsumen dapat diterapkan pada e-commerce kepuasan konsumen akan meningkat. Sehingga bisa dikatakan bahwa e-commerce juga memiliki hubungan dengan kepuasan konsumen. Dengan e-commerce memudahkan konsumen untuk mencari barang yang diinginkan sesuai dengan kebutuhan dan kecukupan financial konsumen tersebut.

Berdasarkan kajian pustaka di atas, kerangka pemikiran dalam penelitian ini yaitu variabel E-commerce (X) memiliki hubungan dengan variabel kepuasan konsumen (Y).

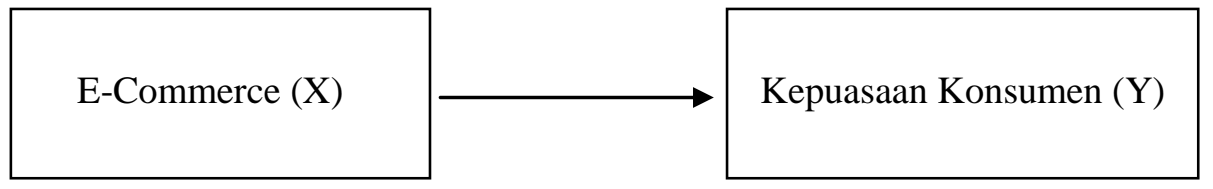

\section{Gambar 2 \\ Kerangka Berpikir}

Berdasarkan kajian teori dan kerangka berpikir yang telah dikemukakan, penulis dapat merumuskan hipotesis penelitian sebagai berikut:

$\mathrm{H}_{1}$ : Diduga terdapat hubungan yang positif dan signifikan antara $e$-commerce dengan kepuasan

konsumen di toko online Rendang Den Lapeh.

\section{METODE}

Penelitian ini merupakan penelitian kuantitatif asosiatif, yang bertujuan untuk mengetahui hubungan antara dua variabel atau lebih. Hubungan kausal adalah hubungan yang bersifat sebab akibat. Jadi, di sini ada variabel independen (variabel yang memengaruhi) dan dependen (dipengaruhi) (Sugiyono, 2015). Penelitian ini dilakukan dengan pemberian angket atau kuesioner kepada responden. Hasil yang didapat diolah menjadi bentuk angka-angka untuk mengetahui hasil dari penelitian yang telah dilakukan, sedangkan hubungan antara e-commerce dengan kepuasan konsumen bersifat asosiatif kausal. Hal ini menunjukkan hubungan antara kedua variabel tersebut memiliki sifat sebab akibat..

Populasi dalam penelitian ini adalah 80 orang customer yang melakukan transaksi pembelian di toko online Rendang Den Lapeh, baik melalui website maupun marketplace selama jangka waktu dua bulan. Kemudian berdasarkan rumus slovin diperoleh jumlah sampel sebanyak 45 orang, Adapun penentuan sampel yang terpilih dalam penelitian ini menggunakan teknik sampling random sederhana. Dikatakan sederhana karena pengambilan anggota dari populasi dilakukan secara acak tanpa memperhatikan strata yang ada dalam populasi tersebut (Sugiyono, 2015b).

Data yang digunakan dalam penelitian ini adalah data primer. Data primer merupakan data yang diperoleh secara langsung dari subjek penelitian (Azwar, 2013). Pengambilan data dilakukan dengan pemberian angket atau kuesioner kepada responden untuk mengetahui pemahaman konsumen terhadap e-commerce secara umum dan penggunaan e-commerce oleh pemilik usaha, serta angket kepuasan konsumen terhadap penggunaan e-commerce dan layanan yang diberikan. kemudian penulis mengolah data untuk mencari hubungan antara kedua variabel tersebut dengan bantuan software SPSS Versi 20. 


\section{HASIL DAN PEMBAHASAN}

Berdasarkan survei terhadap 45 customer yang menjadi responden terlihat bahwa karakteristik customer adalah sebagian besar wanita (75\%), dengan usia antar 25-40 tahun (75\%), dan hampir $80 \%$ customer pendidikannya adalah sarjana. Apabila dilihat dari media yang digunakan oleh responden untuk membeli produk, penggunaan e-commerce yang terdiri dari website toko sendiri, tokopedia, bukalapak dan lazada cukup besar, yaitu sekitar $60 \%$, sisanya adalah melalui whatsaap sekitar $40 \%$ dari responden (Tabel 1).

\section{Tabel 1. Responden Berdasarkan Tempat Pembelian}

\begin{tabular}{clcc}
\hline No & \multicolumn{1}{c}{ Tempat Pembelian } & Jumlah & $\begin{array}{c}\text { Presentase } \\
(\%)\end{array}$ \\
\hline 1 & Website & 7 & $15,56 \%$ \\
& www.rendangdenlapeh.com & & $40 \%$ \\
2 & Whatsapp & 18 & $26,67 \%$ \\
3 & Tokopedia & 12 & $13,33 \%$ \\
4 & Bukalapak & 6 & $4,44 \%$ \\
5 & Lazada & 2 & $100 \%$ \\
\hline \multicolumn{2}{c}{ Total } & 45 & \\
\hline
\end{tabular}

Sumber: data primer yang diolah (2017)

Berdasarkan hasil perhitungan dan penggunaan SPSS version 20.00 diperoleh bahwa data berdistribusi normal (gambar 3). Jika residual berasal dari distribusi normal, nilai-nilai sebaran data akan berada di sekitar garis lurus. Terlihat di gambar 3 bahwa sebaran data berada di sekeliling garis lurus dan tidak terpencar jauh, sehingga dapat dikatakan bahwa persyaratan normalitas bisa dipenuhi.

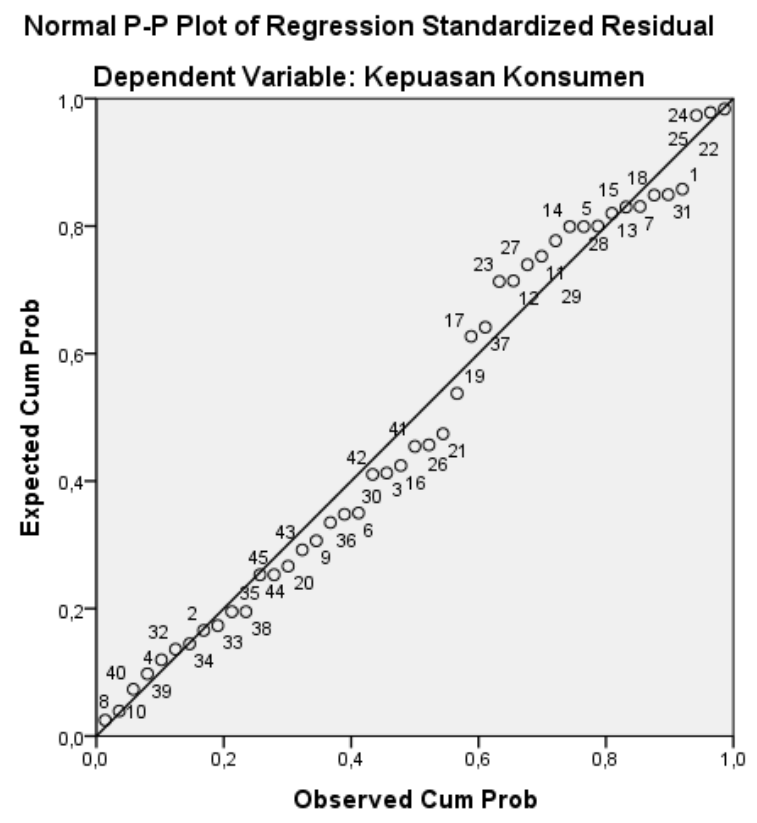

Gambar 3

Pesyaratan Normalitas 
Dari hasil analisis yang ditunjukkan Tabel 2 diperoleh persamaan regresi $\mathrm{Y}=43,157+$ 0,597x, maka nilai konstanta (a) atau nilai tetap dari persamaan 43,157 artinya pada saat kualitas pelayanan sama dengan 0 maka kepuasan konsumen adalah sebesar 43,156 satuan, dan bila b sebesar 0,597 artinya setiap kenaikan $1 \%$ pada e-commerce, maka akan naik kepuasan konsumen sebesar 0,597.

Tabel 2. Nilai Regresi Linier Sederhana Hasil SPSS Ver 20

\begin{tabular}{llrrrrr}
\hline Model & \multicolumn{2}{c}{ Unstandardized Coefficients } & $\begin{array}{l}\text { Standardized } \\
\text { Coefficients } \\
\text { Beta }\end{array}$ & t & Sig. \\
& \multicolumn{1}{c}{ B } & Std. Error & & & \\
\hline \multirow{2}{*}{1} & (Constant) & 43,157 & 9,228 & & 4,677 &, 000 \\
& e-commerce &, 597 &, 132 &, 568 & 4,523 &, 000 \\
\hline
\end{tabular}

a. Dependent Variable: Kepuasan Konsumen

Untuk menguji apakah model regresi tersebut sudah benar atau layak maka perlu pengujian hubungan linieritas antara variabel e-commerce dengan kepuasan konsumen yang ditunjukkan pada Tabel 3. Berdasarkan hasil perhitungan diperoleh nilai sig sebesar 0,000. Angka ini lebih kecil dari 0,05 . Hal ini berarti ada hubungan linier antara variabel e-commerce dengan kepuasan konsumen. Dengan demikian artinya model regresi berpola linier dan sudah layak.

Tabel 3. Nilai ANOVA Hasil SPSS Ver 20

\begin{tabular}{llrrrrr}
\hline \multirow{2}{*}{ Model } & \multicolumn{1}{c}{$\begin{array}{l}\text { Sum of } \\
\text { Squares }\end{array}$} & df & Mean Square & F & Sig. \\
\hline \multirow{3}{*}{1} & Regression & 526,252 & 1 & 526,252 & 20,459 & \multirow{2}{*}{$000^{\text {b }}$} \\
\cline { 2 - 6 } & Residual & 1106,059 & 43 & 25,722 & & \\
\hline
\end{tabular}

a. Dependent Variable: Kepuasan Konsumen

b. Predictors: (Constant), e-commerce

Dari hasil perhitungan didapatkan angka korelasi antar e-commerce dengan kepuasan pelanggan adalah sebesar 0,568 , bisa dilihat dari angka pearson coorelation pada Tabel 4. Hal ini menunjukkan hubungan yang sedang sesuai dengan interpretasi koefisien korelasi yang dikemukakan oleh Sugiyono pada Tabel 5.

Tabel 4. Nilai Koefisien Korelasi dan signifikansi Hasil SPSS Ver 20

\begin{tabular}{llrr}
\hline & & Kepuasan Konsumen & e-commerce \\
\hline \multirow{2}{*}{ Pearson Correlation } & Kepuasan Konsumen & 1,000 &, 568 \\
& e-commerce &, 568 & 1,000 \\
Sig. (1-tailed) & Kepuasan Konsumen &. &, 000 \\
& e-commerce &, 000 & . \\
N & Kepuasan Konsumen & 45 & 45 \\
& e-commerce & 45 & 45 \\
\hline
\end{tabular}




\section{Tabel 5. Interprestasi Koefisien Korelasi}

\begin{tabular}{ll}
\hline Internal Koefisien & Tingkat Hubungan \\
\hline $0,00-0,19$ & Sangat Rendah \\
$0,20-0,39$ & Rendah \\
$0,40-0,59$ & Sedang \\
$0,60-0,79$ & Tinggi \\
$0,80-1,00$ & Sangat Tinggi \\
\hline
\end{tabular}

Sumber: Sugiyono (2015)

Analisa selanjutnya adalah untuk mengetahui pengaruh variabel e-commerce terhadap kepuasan konsumen yang ditunjukan hasil SPSS ver 20 pada Tabel 6. Angka R Square atau koefisien determinasi (KD) pada Tabel 6 adalah sebesar 0,322 atau sama dengan 32,2\%. Angka tersebut mempunyai arti bahwa sebsear $32,2 \%$ vaiabilitas kepuasan konsumen yang terjadi dapat dijelaskan dengan menggunakan variabel e-commerce. Dengan kata lain bahwa besarnya pengaruh variabel e-commerce terhadap kepuasan konsumen adalah $32,2 \%$, sedangkan sisanya, yaitu $67,8 \%$ harus dijelaskan oleh faktor-faktor penyebab lainnya yang berasal dari luar model regresi ini.

Tabel 6. Nilai Koefisen Determinasi Hasil SPSS Ver 20

\begin{tabular}{crrrrr}
\hline Model & R & R Square & $\begin{array}{c}\text { Adjusted R } \\
\text { Square }\end{array}$ & \multicolumn{2}{c}{$\begin{array}{c}\text { Std. Error of the } \\
\text { Estimate }\end{array}$} \\
\hline 1 &, $568^{\mathrm{a}}$ &, 322 &, 307 & & 5,072 \\
\hline
\end{tabular}

a. Predictors: (Constant), e-commerce

b. Dependent Variable: Kepuasan Konsumen

Kemudian dilakukan Uji hipotesis untuk menguji kebenaran hipotesis yang telah dibuat yaitu pada variabel e-commerce (X) dan variabel kepuasan konsumen (Y). Selanjutnya dilakukan uji signifikan (uji $\mathrm{t}_{\text {hitung }}$ ) dengan rumus sebagai berikut:

$$
t=\frac{r \sqrt{n-2}}{\sqrt{1-r^{2}}}
$$

Dari nilai $\mathrm{r}$ yang diperoleh adalah 0,568 , dengan memasukkan ke dalam rumus di atas akan diperoleh nilai $t_{\text {hitung }}$ sebesar 5,50. Nilai $t_{\text {hitung }}$ akan dibandingkan dengan $t_{\text {tabel. }}$ Dengan sampel sebanyak 45 orang dan menggunakan tingkat kesalahan 5\% uji satu pihak dengan $\alpha$ $=0,05$ dan derajat kebebasan $\mathrm{dk}=(\mathrm{n}-2)$ diperoleh nilai $\mathrm{t}_{\text {tabel }}$ sebesar 1,681. Dari hasil pengujian diperoleh $t_{\text {hitung }}$ sebesar 5,50 dan $t_{\text {tabel }}$ sebesar 1,681, ini berarti bahwa $t_{\text {hitung }}>t_{\text {tabel, }}$ maka $H_{a}$ diterima dan $\mathrm{H}_{\mathrm{o}}$ ditolak. Sehingga dapat diambil kesimpulan bahwa terdapat pengaruh yang positif antara e-commerce dengan kepuasan konsumen.

Dari data-data tersebut bisa dilihat bahwa hubungan antara variabel e-commerce dengan kepuasan konsumen adalah positif dan signifikan. Hal ini berarti penggunaan e-commerce yang baik dan benar oleh perusahaan akan meningkatkan kepuasan pelanggan. Hasil dari penelitian ini didukung oleh teori yang disampaikan oleh (Kotler, 2005), (Hasan, 2008) dan (Aritonang, 2005) bahwa kepuasan konsumen timbul dari adanya respon emosional terhadap produk yang digunakan, khususnya ketika harapan itu lantas dibandingkan dengan persepsinya terhadap kinerja yang diterimanya dengan mengonsumsi produk itu. Jika kinerja gagal memenuhi ekspetasi, pelanggan akan tidak puas. Jika kinerja sesuai dengan ekspetasi, pelanggan akan puas. Jika kinerja melebihi ekspetasi, pelanggan akan sangat puas dan senang.. Dri hasil 


\section{sosio e-kons}

Volume 12, No. 2, Agustus 2020, pp. 125-137

e-ISSN: 2502-5449

p-ISSN: 2085-2266

DOI : 10.30998/sosioekons.v12i02.6451

penelitian tersebut yang menyatkan bahwa e-commerce berpengaruh terhadap kepuasan konsumen berarti menunjukkan kinerja e-commerce sama atau di atas ekspetasi dari konsumen sehingga konsumen puas dan senang untuk berbelanja di took ini.

Beberapa penelitian sebelumnya juga menunjukkan hal yang sama bahwa penggunaan dan pengelolaan e-commerce yang baik dan benar akan meningkatkan kepuasan konsumen. Beberapa penelitian yang sejalan dengan hasil penelitian ini antara lain (Sidharta \& Boy Suzanto, 2015) dan (Astuti \& Salisah, 2016) yang menyatakan bahwa kepuasan konsumen dalam berbelanja online ini sangat tergantung dari pelayanan e-commerce yang baik dan professional. Kemudian (Karmawan, 2014) (Lestari, 2018) juga menyatakan bahwa kepuasan konsumen dalam bertransaksi secara online sangat bergantung kepada pengelolaan e-commerce yang baik. Selanjutnya penelitian dari (Setyaningsih, 2014) dan (Widyanita, 2018) menunjukkan bahwa tingkat kualitas layanan e-commerce berpengaruh positif signifikan terhadap Kepuasaan Konsumen. Adapun (Sarah, 2015) dari Universitas Indraprasata PGRI dalam penelitiannya yang menggunakan metode penelitian kuantitatif dan menghasilkan kesimpulan bahwa ada pengaruh yang siginifikan atau sangat kuat antara kepuasan pelanggan dengan pembelian barang pada akun twitter @ShoutCap.

\section{SIMPULAN}

Berdasarkan hasil dan pembahasan dapat disimpulkan bahwa terdapat hubungan yang positif dan pengaruh yang signifikan antara variabel e-commerce dengan kepuasan konsumen. Hal ini dibuktikan dengan angka korelasi antara e-commerce dengan kepuasan pelanggan adalah sebesar 0,568 yang berarti memiliki hubungan yang positif, dan dari hasil pengujian hipotesis diperoleh $t_{\text {hitung }}$ sebesar 5,50 dan $t_{\text {tabel }}$ sebesar 1,681, ini berarti bahwa $t_{\text {hitung }}>t_{\text {tabel }}$, maka Ha diterima dan Ho ditolak. Sehingga dapat diambil kesimpulan bahwa terdapat pengaruh yang signifikan antara e-commerce dengan kepuasan konsumen. Hal ini berarti bahwa penggunaan $e$ commerce yang baik dan professional dapat meningkatkan kepuasan konsumen.

\section{SARAN}

Berdasarakan hasil penelitian yang telah dilakukan, beberapa saran yang bisa disampaikan terutama untuk pelaku UKM yang terkait adalah pelayanan yang diberikan saat melayani setiap pertanyaan customer perlu diperhatikan, hal ini konsumen sendiri merasa dihargai atau tidak dibedakan saat diberikan layanan walaupun tidak secara tatap muka langsung. Pengiriman barang yang tepat waktu dan selalu tersedianya stok barang juga menjadi salah satu faktor penting lainnya. Kemasan yang menarik dan sangat mudah di bawa oleh konsumen untuk bepergian serta tersedianya varian menu, ukuran, paket hemat, mempertahankan packging yang sudah sesuai saat ini dan penambahan diskon kepada para konsumen agar menarik keinginan konsumen untuk membeli.

Saran untuk penelitian selanjutnya adalah perlu ditambah jumlah variable penelitian dan objek penelitian UKM, sehingga hasil penelitian akan lebih lengkap dan komprehensip.

\section{DAFTAR RUJUKAN}

Aritonang, L. R. (2005). Kepuasan Pelanggan Pengukuran dan Penganalisisan dengan SPPS. Jakarta. Gramedia.

Astuti, D., \& Salisah, F. N. (2016). Analisis Kualitas Layanan E-commerce Terhadap Kepuasan Pelanggan Menggunakan Metode E-Servqual ( Studi Kasus: Lejel Home Shopping 
Pekanbaru ). Jurnal Rekayasa Dan Manajemen Sistem Informasi, Vol.2,(No.1, Februari 2016), hal.44-49, e-ISSN 2502-8995 p-ISSN 2460-8181. http://ejournal.uinsuska.ac.id/index.php/RMSI/article/view/1784

Azwar, S. (2013). Metode Penelitian. Yogyakarta. Pustaka Pelajar.

Chandra, Ahmad dan Dadang, H. (2013). E-bussiness and E-commerce. Yogyakarta. Andi.

Diana, A. dan F. T. (2007). E-Business. Yogyakarta. Andi.

Fasanghari, M. and F. H. R. (2008). The fuzzy evaluation of e-commerce customer satisfaction. World Applied Sciences Journal, 4(2), 164-168.

Hasan, A. (2008). Marketing Edisi Baru. Yogyakarta. Media Pressindo.

Hidayat, T. (2008). Panduan Membuat Toko Online dengan OSCommerce. Jakarta. Mediakita.

Insana, D. R. M., Hapsari, A., \& Mayndarto, E. C. (2019). Increasing Entrepreneurial Creativity Through the Introduction of Information Technology Utilization. The 1st Workshop on Multimedia Education, Learning, Assessment and Its Implementation in Game and Gamification in Conjunction with COMDEV 2018, Medan Indonesia, 26th January 2019, WOMELA-GG. https://doi.org/10.4108/eai.26-1-2019.2283330

Insana, D. R. M., \& Hapsari, A. T. (2019). Peningkatan Efektivitas Berwirausaha Melalui Pemanfaatan Teknologi Informasi. Simposium Nasional Ilmiah Dengan Tema: (Peningkatan Kualitas Publikasi Ilmiah Melalui Hasil Riset Dan Pengabdian Kepada Masyarakat), ISBN: 978-623-90151-7-6 DOI: 10.30998/Simponi.V0i0.456, 7 November 2019, 1053-1059. https://doi.org/10.30998/simponi.v0i0.456

Irawan, H. (2008). 10 Prinsip Kepuasan Pelanggang. Jakarta. Elex Media Komputindo.

Irmawati, D. (2011). Pemanfaatan E-commerce Dalam Dunia Bisnis. Orasi Bisnis, VI(November), 95-112.

Karmawan, I. G. M. (2014). Dampak Peningkatan Kepuasan Pelanggan dalam Proses Bisnis Ecommerce pada Perusahaan Amazon.Com. ComTech: Computer, Mathematics and Engineering Applications, 5(2), 748. https://doi.org/10.21512/comtech.v5i2.2237

Kassim, N., \& Asiah Abdullah, nor. (2010). The effect of perceived service quality dimensions on customer satisfaction, trust, and loyalty in e-commerce settings: A cross cultural analysis. Asia Pacific Journal of Marketing and Logistics, 22(3), 351-371. https://doi.org/10.1108/13555851011062269

Komputer, W. (2002). Apa dan Bagaimana E-commerce (2nd ed.). Yogyakarta. Andi.

Kotler, P. (2005). Manajemen Pemasaran Terjemahan (Edisi Kese). Jakarta. PT. Indeks.

Laudon, K. . dkk. (2007). Sistem Informasi Manajemen (Edisi 10 B). Jakarta. Salemba Empat.

Lestari, F. A. P. (2018). Pengaruh Web E-commerce, Kualitas Produk dan Kualitas Layanan terhadap Kepuasan Konsumen. Jurnal Sosio E-Kons, Vol. 10,(No.1, 2018), hal.87-95, eISSN: 2502-5449 ; p-ISSN: 2085-2266. https://doi.org/10.30998/sosioekons.v10i1.2411

Maya, S. (2016). Strategi Peningkatan Penjualan Usaha Kecil Menegah Melalui E- Commerce Studi Kasus: Mitra UKM Perusahaan X. JABE; Journal of Applied Business and Economics, Vol.2,(No.3, Maret 2016), 271-279.

Nisar, T. M., \& Prabhakar, G. (2017). What factors determine e-satisfaction and consumer spending in e-commerce retailing? Journal of Retailing and Consumer Services, 39, 135144. https://doi.org/10.1016/j.jretconser.2017.07.010

Norhermaya, Y. A. (2016). Analisis Pengaruh Kepuasan Pelanggan Terhadap Kepercayaan Dan Loyalitas Pelanggan Untuk Meningkatkan Minat Beli Ulang (Studi Kasus Online Store Lazada.Co.Id). Skripsi Fakultas Ekonomika Dan Bisnis Universitas Dipenogoro Semarang.

Sarah, N. (2015). Pengaruh Kepuasan Pelanggan Terhadap Pembelian Barang Melalui Media Online (Studi Kasus Pembelian Brang Melalui Akun Twitter@ShoutCap. Skripsi. Program Sarjana Fakultas Ilmu Pendidikan Dan Pengetahuan Sosial Universitas Indraprasta PGRI. Jakarta. 
Setyaningsih, O. (2014). Pengaruh Persepsi Kualitas Pelayanan E-commerce Terhadap Kepuasan Pelanggan, Kepercayaan Dan Loyalitas Pada Produk Fashion. Jurnal Bisnis Dan Manajemen, 14(2), 67-80.

Sidharta, I., \& Boy Suzanto. (2015). Pengaruh Kepuasan Transaksi Online Shopping Dan Kepercayaan Konsumen Terhadap Sikap Serta Perilaku Konsumen Pada E-commerce. Jurnal Computech \& Bisnis, Vol.9,(No.1, Juni 2015), 23-36, ISSN 2442-4943. http://jurnal.stmik-mi.ac.id/index.php/jcb/article/download/124/148

Sugiyono. (2015a). Metode Penelitian Kuantitatif Kualitatif dan R\&D. Bandung. Alfabeta.

Sugiyono. (2015b). Statistika untuk Penelitian. Bandung. Alfabeta.

Tjiptono, Fandy dan Chandra, G. (2016). Service Quality and Satisfaction (4th ed.). Yogyakarta. Andi.

Varmaat, S. C. (2007). Discovering Computers: Menjelajah Dunia Komputer Fundamental (3rd ed.). Jakarta. Salemba Infotek.

Widyanita, F. A. (2018). Analisis Pengaruh Kualiatas Pelayanan E-commerce Terhadap Kepuasan Konsumen Shopee Indonesia Pada Mahasiswa Fakultas Ekonomi UII Pengguna Shopee. Skripsi Fakultas Ekonomi Universitas Islam Indonesia.

Wong, J. (2010). Internet Marketing For Begginers. Jakarta. Elex Media Komputindo. 